\title{
Thymidine Kinase, Cytosolic
}

National Cancer Institute

\section{Source}

National Cancer Institute. Thymidine Kinase, Cytosolic. NCI Thesaurus. Code C38512.

Thymidine kinase, cytosolic (234 aa, $25 \mathrm{kDa}$ ) is encoded by the human TK1 gene. This protein plays a role in pyrimidine metabolism. 